\title{
Assessment of the Risk of Hemochromatosis in Polytransfused Sickle Cell Patients at the Abidjan Transfusion Therapy Unit
}

\author{
Yassongui Mamadou Sekongo ${ }^{1, ~ *}$, Kabore Saydou², Kouakou Boidy ${ }^{3}$, Kouamenan Sidonie ${ }^{4}$, \\ Kassogue Kadidja ${ }^{5}$, N'Guessan Parfait ${ }^{5}$, Oue Nabo Bertin ${ }^{5}$, Konate Seidou ${ }^{6}$, Sanogo Ibrahima ${ }^{7}$ \\ ${ }^{1}$ Department of Training and Research, National Blood Transfusion Center, Abidjan, Côte D'Ivoire \\ ${ }^{2}$ Laboratory of quality control, National Blood Transfusion Center, Abidjan, Côte D’Ivoire \\ ${ }^{3}$ Hematology Department, Training and Research Unit of Medical Sciences, Abidjan, Côte D’Ivoire \\ ${ }^{4}$ Hemovigilance Service, National Blood Transfusion Center, Abidjan, Côte D’Ivoire \\ ${ }^{5}$ Transfusion Therapy Unit, National Blood Transfusion Center, Abidjan, Côte D'Ivoire \\ ${ }^{6}$ General Direction, National Blood Transfusion Center, Abidjan, Côte D'Ivoire \\ ${ }^{7}$ Hematology Service, Teaching Hospital Center of Yopogon, Abidjan, Côte D'Ivoire
}

Email address:

sekyass@yahoo.fr (Y. M. Sekongo)

*Corresponding author

To cite this article:

Yassongui Mamadou Sekongo, Kabore Saydou, Kouakou Boidy, Kouamenan Sidonie, Kassogue Kadidja, N'Guessan Parfait, Oue Nabo Bertin, Konate Seidou, Sanogo Ibrahima. Assessment of the Risk of Hemochromatosis in Polytransfused Sickle Cell Patients at the Abidjan Transfusion Therapy Unit. American Journal of Biomedical and Life Sciences. Vol. 8, No. 1, 2020, pp. 20-24.

doi: 10.11648 j.ajbls.20200801.15

Received: January 15, 2020; Accepted: January 27, 2020; Published: February 7, 2020

\begin{abstract}
In Côte d'Ivoire, sickle cell disease affects $14 \%$ of the population. It is responsible for significant morbidity and mortality. Transfusion is a significant element in the management of major sickle cell anemia, which exposes them to posttransfusion hemochromatosis. The biological diagnosis is based on the determination of serum iron and the transferrin saturation coefficient (CST). As the determination of the CST was not available in our exercise context in Côte d'Ivoire, we determined only the ferritinemia. The interest of this work lies in the therapeutic implication linked to the identification of patients at risk of hemochromatosis because chelators are difficult to access for most patients. This was a prospective, descriptive and analytical study, on polytransfused sickle cell patients, followed at the transfusion therapy unit (UTT) of the CNTS of Abidjan, from 2010 to 2018 . We included 78 sickle cell patients, all ages and genders who have received at least ten transfusions. The ferritinemia assay was carried out by ELISA. Transfusion exchange, with $59 \%$ of cases, was the most used mode of transfusion. The mean ferritinemia was $1719.19 \mathrm{ng} / \mathrm{ml}$. Hyperferritinemia was found in $63 \%$ of patients. Most of the patients were on a long-term transfusion program with an average of 27.5 bags of red blood cell concentrates. Thirty-two patients had received at least 20 bags of red blood cell concentrates. We noted 21 patients treated, including 3 with deferoxamine and 18 treated with oral deferasirox. We have identified 33 sickle cell anemia patients at risk for hemochromatosis. The determinants of the risk of hemochromatosis were the high number of blood bags and the method of transfusion.
\end{abstract}

Keywords: Hemochromatosis, Sickle Cell Disease, Tranfusion

\section{Introduction}

The complications of sickle cell disease require transfusion therapy in its severe forms. People whose treatment involves iterative transfusions are exposed to frequent complications including hemochromatosis or hemosiderosis. 
Hemochromatosis is the body's iron overload.

There are two types of hemochromatosis: the genetic form and the secondary forms. These secondary forms are linked to iterative transfusions [1 - 4].

The biological diagnosis of post transfusion hemochromatosis is based on the determination of ferritinemia and the determination of the transferrin saturation coefficient (CST) [5]. The diagnosis of posttransfusion hemosiderosis is suspected in the case of ferritinemia greater than $1000 \mathrm{ng} / \mathrm{mL}$, measured after the transfusion of at least 20 bags of red blood cell concentrates $[6,7]$

Post transfusion hemochromatosis is not documented in Côte d'Ivoire. Very few doctors research it to their polytransfused patients. In France, although notification of post-transfusion hemosiderosis has been compulsory since 1994 in the French haemovigilance network, it has so far been largely ignored despite the obligation to report cases [8]

We are interested in the identification of patients at risk of hemochromatosis by measuring only ferritinemia

The objective of our work was to contribute to the description of the development of sickle cell anemia in Côte d'Ivoire.

\section{Methodology}

It was a retrospective, prospective, descriptive and analytical study on polytransfused sickle cell patients followed in the transfusion therapy unit (UTT) of the National Blood Transfusion Center of Abidjan in Côte d'Ivoire, from 2010 to 2018. The study concerned patients collected over a period of 8 years. The work lasted 5 months from May to September 2018.

Our Study Population concerned 78 major sickle cell anemia patients, of all ages and of all sexes, admitted to this unit and having benefited from at least ten (10) transfusions.

We proceeded by simple random sampling of consenting polytransfused sickle cell patients followed at the UTT.

We included polytransfused sickle cell patients followed at UTT who received at least ten transfusions and who benefited from the ferritinemia test during our study period. We excluded all patients with an infectious and / or inflammatory syndrome and those with a sickle cell vasoocclusive crisis.

The biological material used for the study consisted mainly of venous blood taken from a dry tube after the informed consent of each patient.

The ferritinaemia assay of patients was carried out by the ELISA technique (Enzyme-Linked- Immuno-Sorbent- Assay) according to the manufacturer's recommendations on a "Mini-Vidas"

The data collected was entered using EXCEL 2013 software.

The study was carried out using software EPI. INFO version:

The statistical analysis of the data and the preparation of tables and figures was done using EPI INFO software version
7.2.2.6 and Excell 2010 software.

\section{Results}

\subsection{Epidemiologicals Aspects}

Table 1. Distribution according epidemiologicals aspects.

\begin{tabular}{llll}
\hline PARAMETERS & & NUMBER & PERCENTAGE \\
\hline Phénotype Hémoglobinique & & & \\
& SSFA2 & 50 & 64,1 \\
& SFA2 & 26 & 33,3 \\
& SC & 1 & 1,3 \\
& SAFA2 & 1 & 1,3 \\
Age group & & 78 & 100 \\
& & & \\
& $<15$ & 26 & 33 \\
& $15-30$ & 41 & 53 \\
& $31-45$ & 8 & 10 \\
Sex & $46-60$ & 3 & 4 \\
& TOTAL & 78 & 100 \\
& & & \\
& Femal & 38 & 49 \\
& Male & 40 & 51 \\
& TOTAL & 78 & 100 \\
& Sex-ratio: 1,05 & \\
\hline
\end{tabular}

\subsection{Biological and Therapeutic Aspects}

\subsubsection{Distribution of Patients by Ferritin Level}

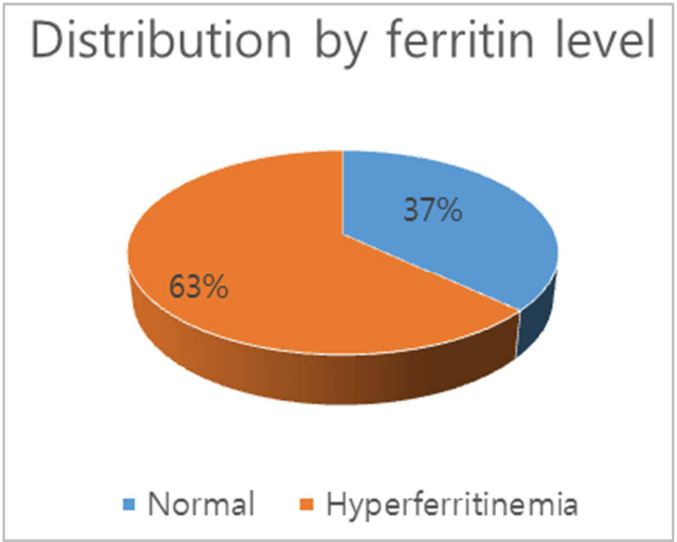

Figure 1. Distribution by ferritin level.

\subsubsection{Transfusion Mode}

Table 2. Patients distribution according to the method of transfusion

\begin{tabular}{lll}
\hline TRANSFUSION MODE & NUMBER & PERCENTAGE (\%) \\
\hline Simple Transfusion & 32 & 41 \\
Exchange Transfusion & 39 & 50 \\
Exchange and Simple Transfusion & 07 & 9 \\
TOTAL & 78 & 100 \\
\hline
\end{tabular}

The half of the sickle cell patients (39) in our study had exchange transfusion i.e. $50 \%$, versus 32 patients for simple transfusion, i.e. $41 \%$. 


\subsubsection{Number red Cells Pockets Transfused}

Table 3. Distribution of patients according to the number of red cells bags transfused.

\begin{tabular}{lll}
\hline $\begin{array}{l}\text { NUMBER OF RED CELLS } \\
\text { BAGS TRANSFUSES }\end{array}$ & NUMBER & $\begin{array}{l}\text { PERCENTAGE } \\
(\%)\end{array}$ \\
\hline 10 à 20 & 30 & 38,46 \\
21 à 30 & 32 & 41,03 \\
31 à 40 & 10 & 12,82 \\
41 à 50 & 01 & 1,28 \\
51 à 60 & 02 & 2,56 \\
61 and plus & 03 & 3,85 \\
TOTAL & 78 & 100 \\
\hline
\end{tabular}

\subsection{Treatment of Hemochromatosis}

\subsubsection{Whether or Not Treatment}

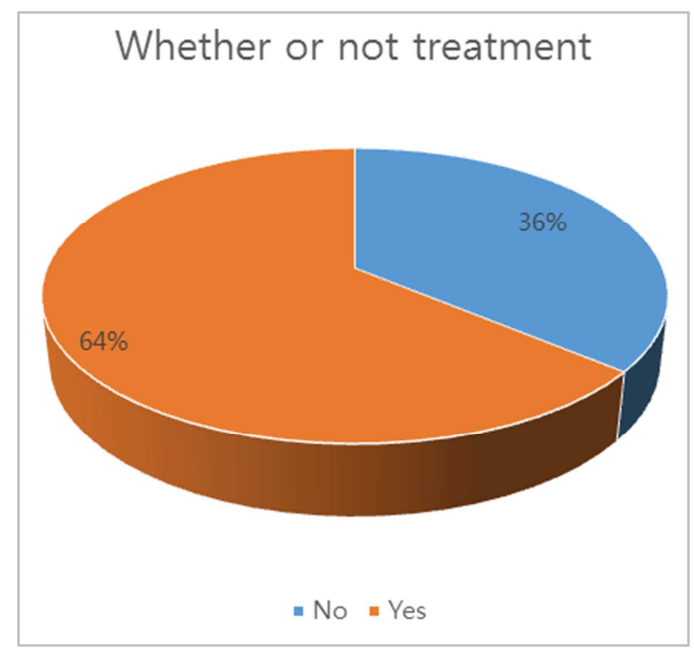

Figure 2. Distribution of patients at risk of hemochromatosis according to the existence or no treatment.

\subsubsection{The Type of Chelating Treatment}

Table 4. Distribution of treatment according to the type of iron chelator.

\begin{tabular}{lll}
\hline TYPE OF CHELATING & NUMBER & PERCENTAGE \\
\hline DEFEROXAMINE & 03 & 14,29 \\
DEFERIPRONE & 00 & 00 \\
DEFERASIROX & 18 & 85,71 \\
TOTAL & 21 & 100 \\
\hline
\end{tabular}

\subsection{Evolution of Post Transfusion Hemochromatosis}

Table 5. Distribution of patients according to evolution.

\begin{tabular}{llll}
\hline & HEALED & DEAD & TOTAL \\
\hline TREATED & 21 & 00 & 21 \\
UNTREATED & 00 & 06 & 12 \\
TOTAL & 21 & 06 & 27 \\
\hline
\end{tabular}

\section{Discussion}

In our study, the average age of our sickle cell patients was 21 years. The age group between 15 and 30 years predominated with 41 patients $(53 \%)$. We found $26(33 \%)$ patients under 15 years of age while, $11(14 \%)$ patients were between 30 and 60 years old. This shows that the majority of sickle cell patients are young. Our work corroborates those carried out in Côte d'Ivoire and and other counties of Africa. ELIRA D and al [9] in Congo reported an average age of $21.8 \pm 3.7$ with extremes of 2 and 45 years.

Our study included adults, proving that the sickle cell major lives beyond 15 years $[8,9]$ The improvement in the life expectancy of sickle cell patients in Africa has been widely documented by Sangare and al [10]. This is explained by protocols for the early management of sickle cell anemia from birth, including the use of antianemia, vasodilators, non-steroidal anti-inflammatory drugs $[11,12]$.

The sex-ratio in our study was 1.05 with $51 \%$ for men and $49 \%$ for women. There is therefore no tendency towards any sexual predisposition of the affection.

The anemic forms of sickle cell anemia (SSFA2 and SFA2) represented $64.10 \%$ and $33.34 \%$ respectively, so they are the most exposed to complications. Our results are similar to those of Sekongo and Coll. [13] who obtained for the phenotypes SSFA2, SFA2, SAFA2 and SC respectively $57.24 \%, 25.52 \%, 2.07 \%$ and $15.17 \%$. This predominance of anemic forms in our study population is logical since they were patients selected on the base of polytransfusion.

The mean of ferritinemia was $1,719.19 \mathrm{ng} / \mathrm{ml}$. This ferritinemia ranged from $55 \mathrm{ng} / \mathrm{ml}$ to $8800 \mathrm{ng} / \mathrm{ml}$ with $63 \%$ hyperferritinemia (49 patients) and 37\% normal ferritinemia (27 patients). Our results are superior to those of Raouf Hafsia et al. [14] in Tunisia who found in their study an average ferritinemia at $660.35 \mathrm{ng} / \mathrm{ml}$ with extremes of 4.89 and $3360 \mathrm{ng} / \mathrm{ml}$ ) in their sickle cell patients.

Out of a total of 49 hyperferritinemic patients:

16 patients $(33 \%)$ had a ferritinemia between 200 or 300 and $1000 \mathrm{ng} / \mathrm{ml}$,

33 patients $(67 \%)$ had ferritinemia above $1000 \mathrm{ng} / \mathrm{ml}$ who presented with hemochromatosis. Our results are superior to those of Raouf Hafsia and al. [14] who found ferritinemia levels greater than $1000 \mathrm{ng} / \mathrm{ml}$ in only $23.41 \%$ of their polytransfused sickle cell patients.

The transfusion exchange with $50 \%$ was the most used mode. The patients, in general, were in transfusion program because they had complications such as stroke, priapism, leg ulcer or severe forms of vaso -occlusive crisis, pregnancy, osteonecrosis.

For simple transfusions, the majority of patients did so as part of ad hoc therapy with severe anemia as an indication.

For normal ferritinaemia, the majority of patients had benefited from the transfusion exchange. The transfusion exchange had an influence on the ferritinemia despite the fact that it was mechanical thus obliging to bleed before transfusing. Today the transfusion therapy unit has within it an "OPTIA" type erythrapheresis device. According to De Montalembert M., [2] the practice of erythrapheresis (transfusion exchange using a cell separating machine) seems to avoid this serious disadvantage

The majority of our patients were on a long-term 
transfusion program, hence the increase in the number of transfusions with an average of 27.5 red blood cells and the risk of iron overload.

Among 33 hyperferritinemic patients at risk of hemochromatosis, $21(61 \%)$ were treated and $12(36 \%)$ untreated

Regarding management, 32 out of 33 patients at risk for hemochromatosis had received at least $20(97 \%)$ red blood cells. This result corroborates that of the committee of experts of the Limonsin hematology network which states: "from 20 globular pellets with ferritinemia at $1000 \mathrm{ng} / \mathrm{ml}$, it is absolutely necessary to chelate" [15]. In our study, one patient (3) escaped this committee rule, which should be notified. The finding made at the UTT of the Abidjan CNTS has been proven. In this unit it would therefore be recommended to make the chelation from 10 transfusions with a ferritinemia above $1000 \mathrm{ng} / \mathrm{ml}$.

In our study, the determinants of hemochromatosis risk were the number and the mode of transfusions.

the average of ferritinemia in 33 patients at risk of hemochromatosis was $4680.86 \mathrm{ng} / \mathrm{ml}$ with the ferritin level between $1066 \mathrm{ng} / \mathrm{ml}$ and 9540ng/ml $(\mathrm{p}=0.0000)$.

The average number of Red blood Cell received by patients at risk for hemochromatosis was 35 bags with extremities from 17 to 74 bags $(p=0.0001)$.

Our results corroborate those of Fung EB and Coll [16] as well as Harmatz P et al. [17] who all reported in their studies a significant correlation between increased ferritinemia and the number of red blood cells transfused in sickle cell patients. Davies and al [18], by evaluating ferritinemia in 31 homozygous sickle cell patients, showed that it was significantly higher in polytransfused patients

Out of a total of 33 hyperferritinemic patients at risk of hemochromatosis, 26 (79\%) patients practiced simple transfusion and 01 (3) patient for transfusion exchange $(\mathrm{p}=$ 0.00000).

For 33 hyperferritinemic patients at risk of hemochromatosis, 21 (64\%) were treated and $12(36 \%)$ untreated. Among the patients treated, 03 (14,29\%) had used deferoxamine as a subcutaneous or intravenous injection for at least two months and $18(85.71 \%)$ patients or were treated with deferasirox for at least two months by the oral route. Deferasirox also offers an alternative to subcutaneous infusions for children from 2 years of age. Treatment with deferasirox met with patient support and markedly increased adherence to chelating therapy. The same observations have been made by Brittenham GM [19] and Clara Camaschella [20].

The patients who had been treated with iron chelation were all cured of iron overload. For those who could not be treated either because of the cost of treatment or the shortage of the drug, or because of late detection, half were deceased Hemochromatosis in sickle cell anemia is a factor of mortality.

\section{Conclusion}

At the end of our study, we identified 33 polytransfused sickle cell patients at risk of hemochromatosis. The determinants of the risk of hemochromatosis were the number and the mode of transfusions.

Our study highlights the need to inform patients about certain aspects of their management, to ask and carefully measure the indication for transfusion in the event of even marked anemia. It would be recommended to start chelation beyond 20 administered red blood cells bags, as soon as the ferritinemia is above $1000 \mathrm{ng} / \mathrm{ml}$. The practice of transfusion exchanges, automated or manual, will limit the risk of iron overload. However, the cost of ferritin dosing must be within everyone's reach and considered as a routine exam in polytransfused sickle cell anemia. Chelators must be accessible and available in pharmacies.

\section{Conflict of Interest}

All the authors do not have any possible conflicts of interest for this manuscript.

\section{References}

[1] Montalembert (de) M. transfusion in Sickle cell disease In GIROT R., BÉGUÉ P, GALACTÉROS F. eds. The Sickle cell disease. Paris; John Libbey Eurotext 2003: 247-253.

[2] Marianne de Montaleùbert Therapeitique option in the sickle cell disease. THE PRACTITIONER'S REVIEW / 2004: 54 $1558-1567$.

[3] Yawn B. P., Buchanan GR., Afenyi-Annan A. N. et cill. Management of sickle cell disease: summary of the é014 evidence-based report of expert panel members. JAMA, 2014, 312, 1033-1048.

[4] Piel FB, Steinberg MH, Rees DC. Sick Cell Disease. N Engl J Med 2017; 376: 1561-1573.

[5] French Federation of Patients Associations with Hemochromatosis. the diagnosis of Hemochromatosis https://www.hemochromatose.org/hemochromatose/lediagnostic-de-lhemochromatose/.

[6] Waalen J, Felitti VJ, Gelbart T, Beutler E. Screening for hemochromatosis by measuring ferritin levels: a more effective approach. Blood. 2008 Apr; 111 (7): 3373-6.

[7] A Camacho, S Bouhya, P Latry. Posttransfusion hemosiderosis. Transf. Clin. Biol. 2014, 21 (4-5): 273.

[8] S. Leo-Kodeli, P. Renaudier, B. Lassale. Evaluation of transfusion hemochromatosis prevalence, SFVTT-01 study: Preliminary results of the SFVTT working group. Transf. Clin. Biol. 2014, 21 (4-5): 182-188.

[9] Elira-Dokekias A, Ngoloet O L, Atipo T, Malanda F, Koko I, Montalembert M. Evaluation of blood transfusion in 112 sickle cell patients homozygous at Brazzaville University Hospital. Transf clin biol 2009; 16 (5-6): 464-70.

[10] Sangare A, Sanogo I, Meité M, Kple Faget P, Sawadogo S, Segbena A, et al. Contribution to the study of the relationships between sickle cell disease and malaria. Med Afr Noire 1990; 37 (5). 
[11] SangarE A Measures to take in the event of sickle cell disease. Med Prat 1989; 89. P. 2-8.

[12] De Montalembert M., Tshilolo L. Are therapeutic advances in sickle cell disease applicable in sub-Saharan Africa? Med Trop, 2007, 67, 612-616.

[13] Sekongo YM. Prevalence of complications and risk factors in major sickle cell disease [Med These]. Abidjan: UFR Medicale Sciences Univ Cocody; 2002, 3051.

[14] Raouf Hafsia, Fatma Belakhal, Naouel Ben Salah, Emna Gouider, Wijden El Borgi_Evaluation of iron overload during sickle cell anemia: about 94 cases. The Tunisie Medicale 2011; 89 (06): 548 - 552 .

[15] M. Touati, D. Berdessoule, C. Rose. Limousin hematology network (Hematolium) Iron overloads in hemopathies. Latest updated version of 11/22/2012 available on: https://hemato.chu-
limoges.fr/hematolim/Portals/0/Reseau\%20HEMATOLIM/RE F\%20HEM\%20MAL\%2010\%20Surcharge\%20en\%20Fer.pdf.

[16] Fung EB, Harmatz P, Milet M. Morbidity and mortality in chronically transfused subjects with thalassemia and sickle cell disease: A report from the multi-center study of iron overload. Am J Hematology 2007; 82: 255-65.

[17] Harmatz P, Butensky E, Quirolo K. Severity of iron overload in patients with sickle cell disease receiving chronic red blood cell transfusion therapy. Blood 2000; 96: 76-79.

[18] Davies S, Henthorn JS, Win A. Effect of blood transfusion on iron status in sickle cell anaemia. Clin Lab Haematol 1984; 6: $17-22$.

[19] Brittenham GM. Iron-chelating therapy for transfusional iron overload. N Engl J Med 2011; 364 (2): 146-56.

[20] Clara Camaschella, M. D. Treating Iron Overload. The new england journal of medecine. 2013 Juin. 368; 24. R. 